\title{
TERRITORIAL POTENTIALS OF A GREEN ECONOMY
}

\author{
BALÁZS DURAY, PHD \\ Geographer, research fellow \\ Hungarian Academy of Sciences \\ Centre for Regional Studies Alföld Institute (CRS AI) Békéscsaba Department \\ Szabó Dezső u. 42, H-5600 HUNGARY \\ Phone: (+36) 2041389 93, (+36) 66441 801, fax: (+36) 66328 577; e-mail: durayb@rkk.hu
}

\begin{abstract}
The research - which is the base of this paper - examines the effects of different social, economical and ecological driving factors of the land use changes at the border areas of the South Great Plain Region.

The multidimensional model is used to analyze interactions at the landscape-scale, hereby it helps to understand the dynamic of the changes and also contributes to develop "best-practices" at the landscape-planning.

The different kind of land use conflicts depends of the target of spatial planning. This paper tries to present methods and semi-results which can be used to examine the problems.
\end{abstract}

Key words: green economy, spatial development, territorial potential

\section{WHAT IS GREEN ECONOMY? - CONCEPTUAL QUESTIONS OF THE GREEN ECONOMY}

The industrial transformation inducing continuous growth and expansion of economic development, dating from the half of the 19th century, nowadays carries a high volume of environmental stress which exceeds the capacity of the ecosystem. Because the problem is due to the nature of today's economic activity, researchers see the solution in the transformation of the latter.

The main goal of the ecological economics, which is the theoretical foundations of the Green Economy (GE), is to harmonize the economic processes with the natural processes while the economic components are integrating in the ecosystem cycling processes, thus causing the least damage (circular economy, biomimicri).

The primary purpose of switching for the GE (the theory of ecological economics as a baseline) is to reduce the human activities on natural ecosystem processes. Translated into a sectoral approach, this means the reduction of all impacts of the different economic activities on climate change, namely on global warming.

\section{THE GLOBAL GREEN NEW DEAL (GGND)}

By the year of 2008, three global crises occurred simultaneously: the fuel, food and financial. The Global Green New Deal (GGND) (UN 2009) based and developed on the target system of Roosevelt's 
New Deal program in the 1930s, is the United Nations' program getting out from these crises. Its main object is to encourage the development for a global strategy. The United Nations Environment Program (UNEP) discussion paper "A Global Green New Deal" argues that today's multiple crises demand the same kind of government leadership, but at the global scale and embracing a wider vision. A Global Green New Deal is proposed as a manifestation of that leadership.

The three priorities of the GGND are: (1) the economic and environmental long-term sustainability by investing into the "green sectors", (2) developing the regulatory systems of the nations, and (3) the international cooperation. The target of the strategy plan is not only 'greening' of the economy, but also to prepare an incentive system, and try to reduce the global carbon dependency, protect fragile ecosystems and alleviate poverty while promoting economic growth and create jobs.

Consequently, the national development and economic policy basically should be developed in the following three directions:

1) Make a major contribution reviving the world economy, saving and creating jobs, and protecting vulnerable groups;

2) Reduce carbon dependency and ecosystem degradation, putting economies on a path to clean and stable development;

3) Further sustainable and inclusive growth, achievement of the MDGs, and an extreme poverty by 2015 .

The above also means that the new approach of development policy has to be met with two fundamental objectives. These are to reduce carbon dependency and ecosystem degradation.

The works of the UNEP, the Green Economy Initiative and the Green New Deal Group are based on the Green New Deal (UN 2009), - which follows the latest international trends, and becomes more popular at economists - tries to "greening" the economic policies of its members basically in five key areas:

- Old and new buildings for energy efficiency;

- Renewable energy technologies (wind, solar. Geothermal and biomass);

- Sustainable transport technology (hybrid vehicles, public transport, etc.).;

- Ecological factors (water supply, forestry, soil);

- Sustainable agriculture (organic farming).

\section{TERRITORIAL POTENTIALS OF THE GREEN ECONOMY}

In the framework of the analysis of spatial aspects of the green economy, we have examined the territorial impacts of economic development on the basis of the logic of action embedded in the sustainability strategic approach. According to this concept, green economy is virtually the "greening" of the economy through green sectorial development processes, its reinvigoration through the promotion of sustainable entrepreneurial relevant industry and the environment, job creation, the reduction of environmental hazards caused by the industrial sector, the creation of an economy with low pressure environmental which would guarantee the long-term functioning of the ecosystem besides the creation of jobs. The examination of the spatial aspects of the existing efforts to establish domestic green economy was carried out through green sectors (energy saving building industry, renewable energy management, sustainable transport and agriculture, water management, environmental infrastructure), in the meantime, on the basis of the above, due to the horizontal nature of spatial development of the global synthesis of the processes in a real can only through an integrated approach. The objective of the comprehensive integrated "green" spatial development is the protection 
of biological diversity, the development of agribusiness and the rural economies, and the simultaneous consideration of the social policy aspects of the exploitation of natural and cultural (traditional) in order to enhance the opportunities keeping power of population together with the rural areas and employment opportunities to establish an economy adapted to local constraints environmental (ecological agrarian industry). All this must be harmonized with sectorial policy measures directed at the popularization of renewable energy, the development of the agrarian sector and the preservation of natural and cultural values.

In the Territorial Agenda (2011), one of the main aims of the territorial cohesion is a more efficient exploitation of the territorial cohesion by strong local and regional condition potentials. The territorial dimension in the sense is the regional competitiveness, sustainable regional development, and the integration into the European space.

In the background, the potentials of regional green economy sectors can be examined through the dimensions of green sectors. Here are three green sectors representing the Hungarian opportunities in the development of green areas.

\section{SPATIAL ASPECTS OF THE ENERGY MANAGEMENT}

The energy sector is one of the most important parts of "greening the economy". The "greening" perspectives of the energy management can be evident on the energy prices, energy efficiency (building) industry, housing and technology. In the country's total energy consumption the residential and domestic use is the highest (264.000 TJ), followed by institutions (144.000 TJ), and the industry and agriculture. If the energy consumption is examined by territorial review (Fig. 1),

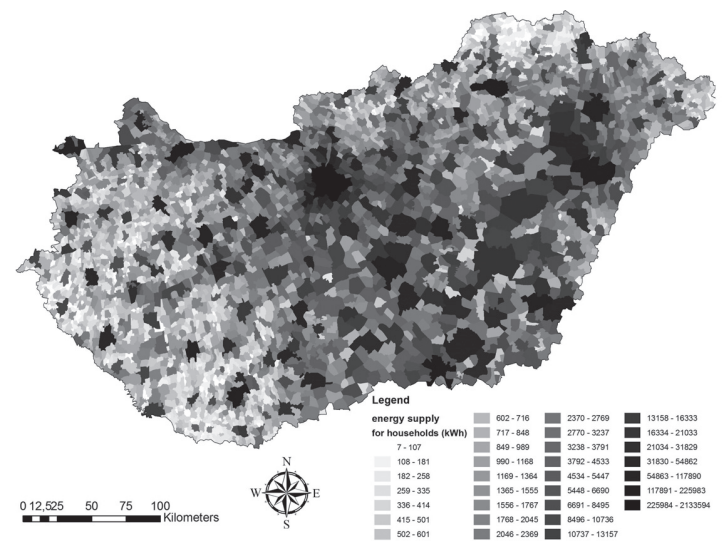

Fig.1. The quantity of electricity supplied to households, 2008 (kWh) (Source: KSH T-STAR¹ 2008, CRS 2010)

examining the differences clearly emerges that the Great Plain has the biggest "energy hunger" with the towns of Szeged, Hódmezővásárhely, Békéscsaba, Debrecen, Nyíregyháza. Miskolc rises out of the line with the higher consumption mainly. The magnitude of income is an indirect energy consumption because the travel habits (eg, train or aircraft), the comfort level, the level in applied

1 Hungarian Central Statistical Office settlement statistical database 
technology (energy efficiency), rules, norms of behavior, attitudes and social habits (e.g. voluntary return of $\mathrm{CO}_{2}$ quota) of the population depend on it frequently. The country's territorial income distribution (such as economic growth indicator) is closely correlating with the energy consumption (Fig. 2.).

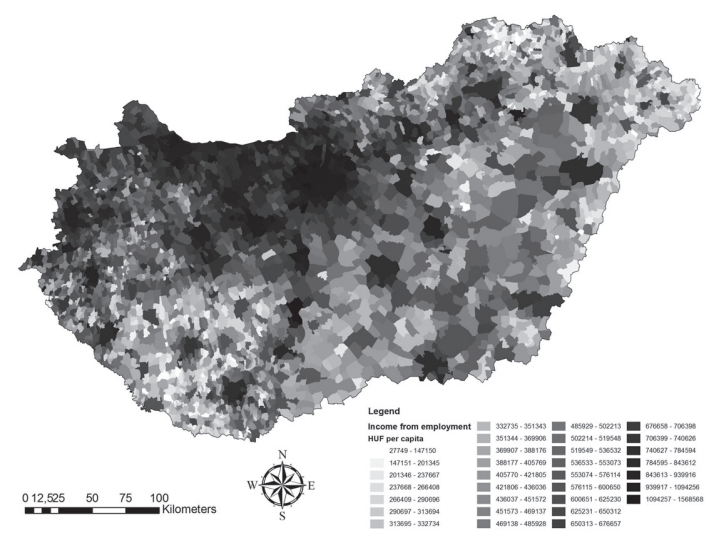

Fig.2. Employment income, 2008

(Source: KSH T-STAR 2008, CRS 2010)

The construction industry is $40 \%$ of the total energy consumption and - during the construction activity - more additional $\mathrm{CO}_{2}$ emissions. The new buildings can contribute most significantly to reduce of $\mathrm{CO}_{2}$ emission with technological innovation. Examining the domestic housing construction volume in 2008 (Fig. 3) we can clearly speak about urban phenomenon.

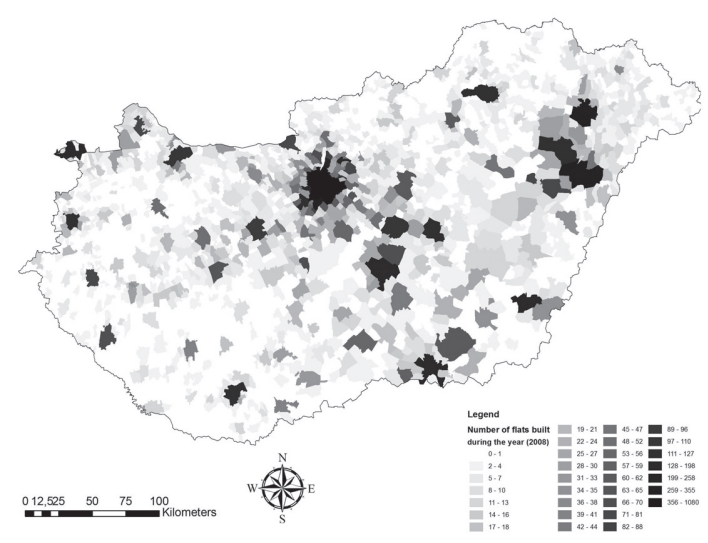

Fig.3. Number of flats built during the year, 2008

(Source: KSH T-STAR 2008, CRS 2010)

Besides all the pollution from the construction processes, starting suburbanization processes with housing stock and housing price increases, because of that the green areas are increasing.(Fig. 4).

More and more people are finding that the use of renewable energies - solar, hydro, wind, geothermal and biomass - could be the key to solve the energy challenges standing in front of humanity. 
These possible applications, can be very different by the areas, if we want to use them correctly, several criteria are needed to be taken.

Considering Hungary, first is advisable to review the kind of available theoretical potential of which how much is sustainably utilized, what scale projects can be made on this plan, the energy balance and emissions (production, transport), taking into account the fact the green economy may be part of it, or what kind of opportunities are giving the future technological developments, and finally what power can be calculated with in the rural areas.

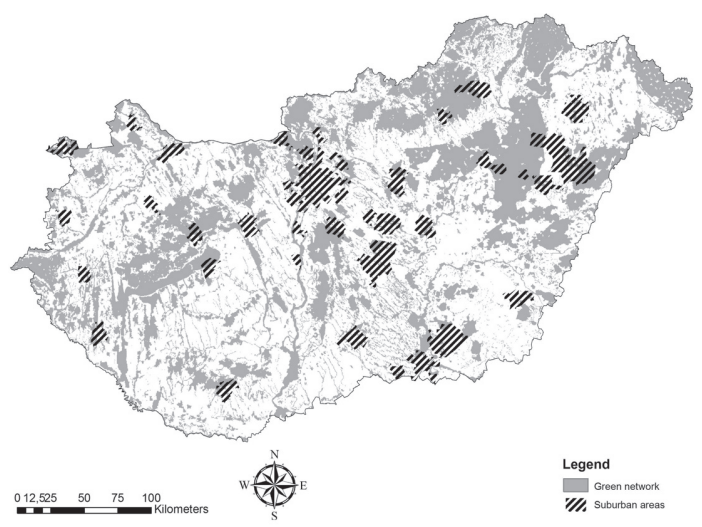

Fig.4. Areas of endangered green network by suburbanization, 2008

(Source: KSH T-STAR 2008, CRS 2010)

Hungary - according to the global trends - has to satisfy the increasing hunger of the population in a way, so that the total energy consumption from renewable energy sources should rise. If Hungary would like to raise the current $4 \%$ share of renewables by $10 \%$, by the year of 2020 , primarily, it has to promote the exploitation of rapid technological development and inventions regulated alternative energy sources. It has to promote its exploitation with rapid pace of technological development and regulated, alternative energy sources. Once the biomass potential is now the largest resource available (38, $3 \%$, but $86 \%$ of firewood together!) expectedly in the near future it will remain, but at the same time improvements are needed in other renewables as well. In the production of electricity apart from the renewables, the biomass and the wind energy have major roles as well. In the production of thermal energy, the natural gas has big role, biomass is about $90 \%$ share in line of renewables, and the geothermal heat has a considerable volume.

The Carpathian Basin, particularly under the area of Hungary, the earth's crust is thinner than the average, so the geothermal circumstances in Hungary are very favorable (Fig. 5). The Earth's interior outward heat flux $90-100 \mathrm{~mW} / \mathrm{m}^{2}$ average value, which is about twice the continental average. The geothermal gradient in Hungary $\left(0,042-0,066^{\circ} \mathrm{C} / \mathrm{m}\right)$ is twice as the Earth's gradient $(0,020-0,033$ ${ }^{\circ} \mathrm{C} / \mathrm{m}$ ). Due to the above mentioned thermal conditions - in the depth of $1000 \mathrm{~m}$ - layer temperature reaches or even exceeds the $60{ }^{\circ} \mathrm{C}$ under our area. The temperature isotherms at a depth of $2000 \mathrm{~m}$ discover large fields above the temperature of $100^{\circ} \mathrm{C}$. The geothermal energy is mainly coming from the thermal water in the Carpathian Basin. Most of the thermal water is used by the agriculture. Firstly heating the crop growing places is efficient.

The amount of solar energy is characterized by two data: the global radiation and sunshine duration (number of hours of sunshine). The global radiation map (Fig. 6) clearly shows that the major 
radiation of our country can be expected at the lowland areas and the places of South Transdanubia. The Southern Great Plains Region is the richest area in our country, concerning the solar energy. The spatial distribution of the solar radiation is homogenous, the region's average is only exceeded in the Tisza valley and along the lower reaches of the Danube. The five-year average radiation data and the region's average considered global radiation averages $\left(466,449 \mathrm{~J} / \mathrm{cm}^{2}\right)$, with high security, can be treated base data for planning solar energy.

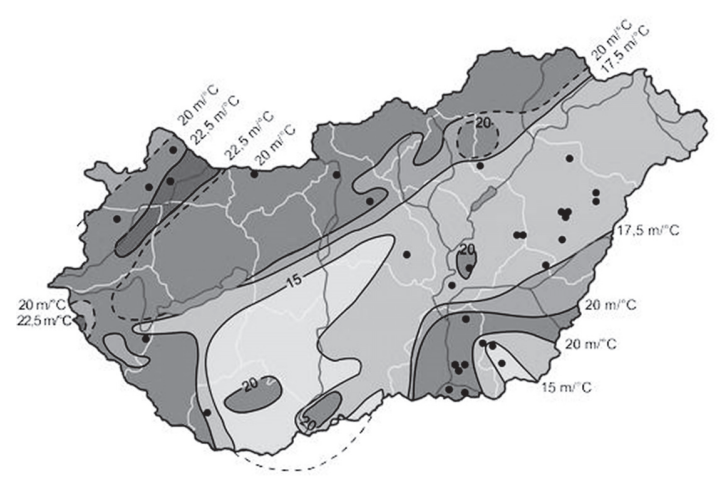

Fig.5. Geothermal gradient

(Source: FÖMI2 2010)

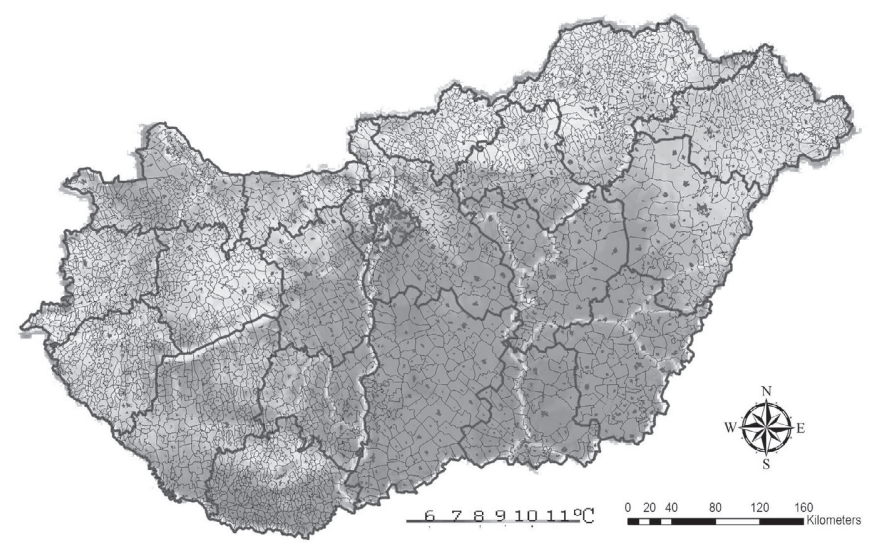

Fig.6. Average annual temperature of Hungary

(Source: OMSZ, 2008)

The growth of green energy is a direct impact on land use, especially for rural land use. It can be an explicit effect on the prices of agricultural products, and indirectly on the farm diversification and the employment. After - looking back on many decades of history - the plain (here: Great-Plain) economic and social problems are mitigated by the improvement of the above mentioned factors. Among the renewable energies, the biomass is given a prominent. The available biomass potential in Hungary is about 360 million tons (2006 data). From this amount, renewable is approximately

2 Institute of Geodesy, Cartography and Remote Sensing 
110 million tons each year, of which 68 million tons are for producing food, animal feed and other uses (e.g. industrial use). The remaining 42 million tons is the theoretical potential energy, of which approximately $420 \mathrm{PJ} /$ year can be energy production, which is $37-38 \%$ energy consumption of 2008 (Dinya 2008). In the biomass production sector increased interest areas can be appointed by the renewable energy sources due to inhomogeneous spatial distribution. The biomass is related to the agricultural activities on the Great Plain. This is the place where the $180 \mathrm{PJ}$ of heat value, nearly 10 million tons of dry biomass are generated.

If we look at the country's total renewable energy potential by sub-regional distribution (Fig. 7), it is evident that Great-Plain (biomass, geothermal), and the forested areas (firewood, biomass), are the best. The Great-Plain's high energy demand (13,680 TJ per year, see Fig. 1) could be satisfied with the local green energy sources (134,341 TJ). Top of it all, the above mentioned could help the domestic realization of a new type local energy supply towards a socio-economic paradigm.

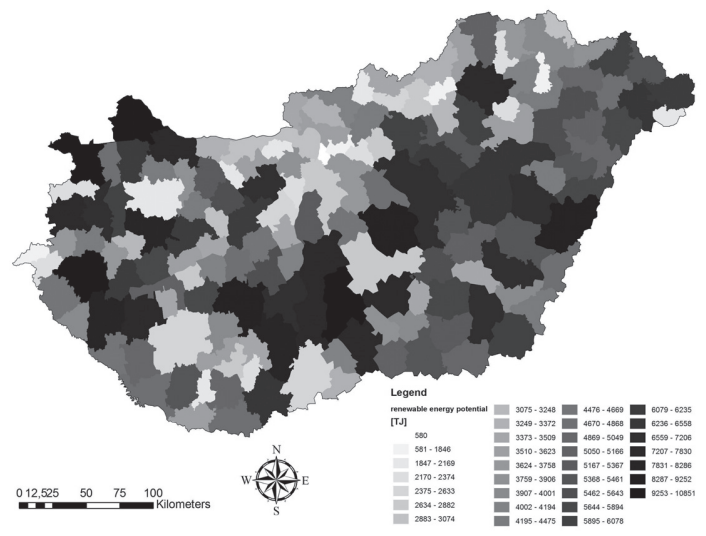

Fig.7. Renewable energy potential (by sub-regional)

(Source: KSH T-STAR 2008, CRS 2010)

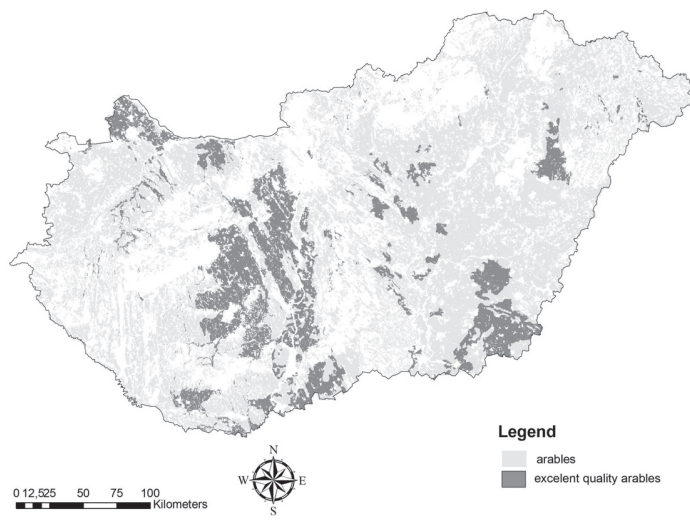

Fig.8. Distribution of excellent quality arable land in Hungary (Source: VÁTI OTrT 2008³, CRS 2010)

${ }^{3}$ Hungarian Public Nonprofit Company for Regional Development and Urban Planning, National Spatial Plan 
It is an important issue - relating to bioenergetics of the long-term sustainability - whether on the available arable we produce energy or food. Based on this, the bioenergy productions and developments should be optimized on smaller areas. The fuel demand of the power stations should be primarily agricultural, municipal and industrial wastes. Besides of that, using the unfavorable endowments (poor quality arable) areas in this process can be possible (Fig. 8).

Another question is whether growing energy crops threatens the landscape and biodiversity or not. In our opinion this is a real danger, even if we have a well-designed land-use concept as well. The plants producing in this way can become "monocultural" or the gene modified pieces can cause harm to the nature with its migration to another place. Especially the nature and water resource protected areas are at risk (Fig. 9 and 10).

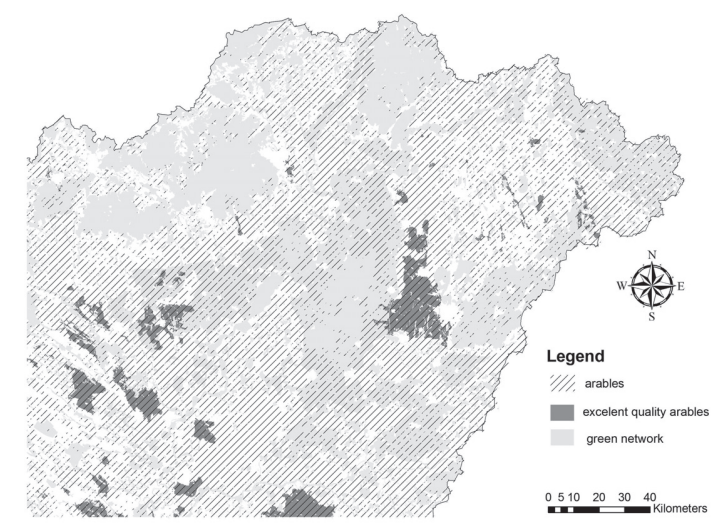

Fig.9. "Hot-Spots" of production of food and energy raw material (Source: VÁTI OTrT 2008, CRS 2010)

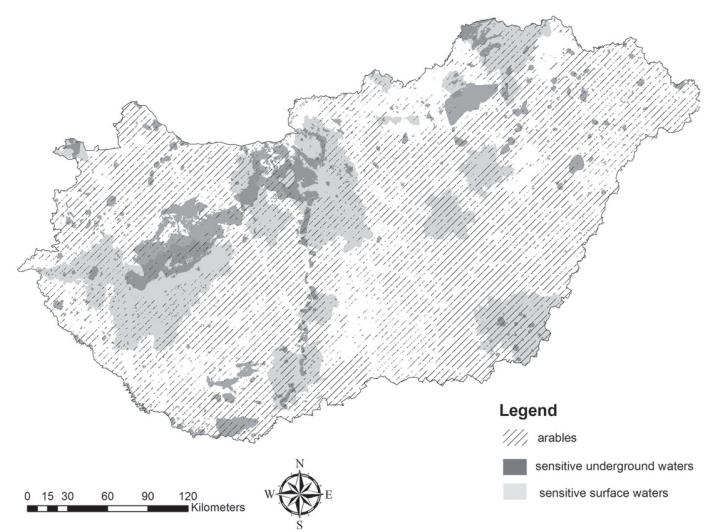

Fig.10. Water quality protection zones of surface waters and arable land conflict zones (Source: VÁTI OTrT 2008, CRS 2010) 


\section{WATER MANAGEMENT}

By the climate models, the period between 2021 and 2040 the climate change in Hungary will have an average $1.2{ }^{\circ} \mathrm{C}$ temperature increase, which will affect all seasons. Regionally in the GreatPlain is higher than in Transdanubia. Although the regional models are not significant, the drying trend is outlined of them. The extreme weather events (storms, heavy rains, hot days) are mentionable which have high influence on the industry and the agriculture. From the models we can figure out that the rainfall intensity will increase, thus the number of heavy rain and storms are expected to increase and the number of small rainfall events associated with thinning will be less. Because of that, the flood risk will increase the drought of summer season and groundwater levels reduce, the latter mainly in the Great Plains.

Overall, by the climate change the surface water and the water runoff formation conditions will change and all of these have a deep effect on the technical infrastructure (eg sewerage and drainage), and related agricultural activities. The ground water can reduce and the metropolitan areas and regional water supply respectively could be under danger (e.g. in Homokhátság area).

The various water use differences (retail, power generation, irrigation, "water footprint" etc) between Transdanubia and Tisza places can be seen. (Fig. 11). The available water resources due to regional differences can clearly show that the water is not always can be found where it is used. The seepage, evaporation, and runoff is not in harmony with the water withdrawals, top of it all, the power supply anomalies and its spatial, quantitative and qualitative differences are added to it.

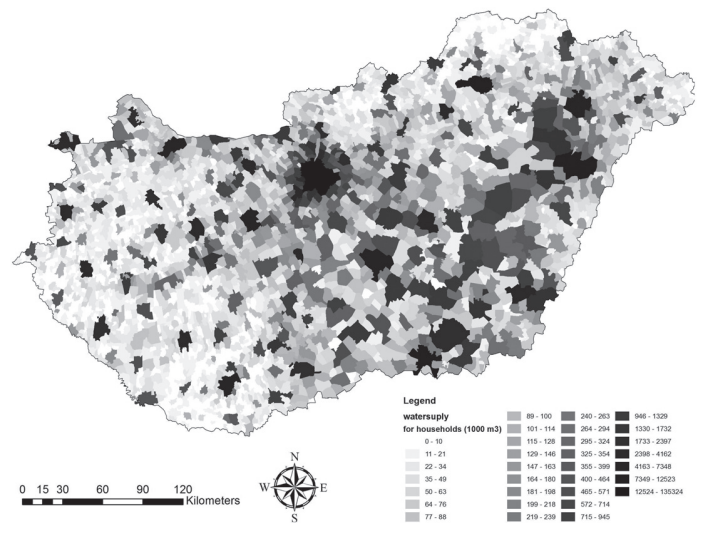

Fig.11. Total quantity of supplied water, 2008

(Source: VÁTI OTrT 2008, CRS 2010)

The guidelines of the Habitat Directive (1992) shows a similar input-output problem by which on the protected areas the water withdrawals should be reduced, at the same time in some regions beyond licensing happens.(see: Natura 2000, Water Framework Directive). The various land use and land cover type are also directly have an effect on the infiltration and runoff (see: drainage, flooding, urban spaces, installation method etc), thereby influencing the amount of surface water bodies (see: irrigation).

Reducing floods is the most common (and also have a territorial dimension) activity during the transition to a low carbon economy. Flood control (indirectly) is the conservation of biodiversity, and also the built and cultural assets (land, buildings etc) protection. All of this, with the appreciation 
of the tourism and leisure activities will be come into view. The various management and social activities in the landscape helps the flood risk reduction but requires intensive researches. Flood risk assessment and the analysis of various interactions of land uses should be a priority area of the integrated spatial analysis.

\section{SPATIAL DEVELOPMENT OPPORTUNITIES OF THE MULTIFUNCTIONAL AGRICULTURE}

The agro-environment scheme is based on the Hungarian land use zone system (Ángyán 2003a) reported that the territory of Hungary by the agricultural suitability and environmental sensitivity indicators, is divided extensive and intensive agricultural area. The land can be classified by the scores in the assessment system (Fig. 12).

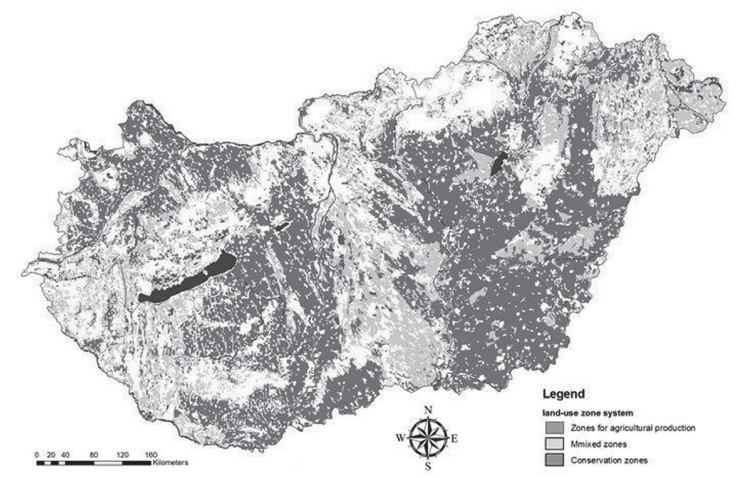

Fig.12. The location of arable land in the proposed land-use zone system (Scenario No2)

(Source: Ángyán 2003b)

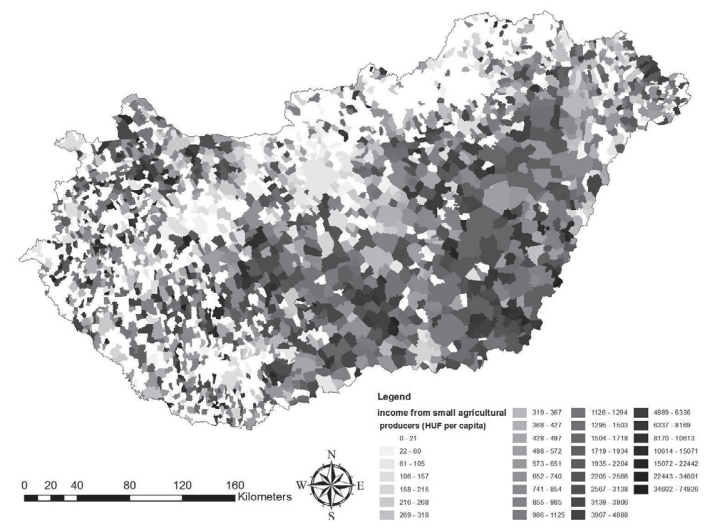

Fig.13. Income from small agricultural producers, 2008 Source: KSH T-STAR 2008, CRS 2010

The aim of the zone system is that the nature conservation areas could be integrated in the economic and social processes through a gradual transition (buffer zones, double-favored areas specified). Considering that, the most of primary producers in Hungary farming on the Great- Plain 
(Fig. 13), which is suitable for intensive agricultural management, furthermore, the extensive and nature conservation areas are important, a major issue is that what the agricultural sector is, in which these producers can thrive.

Our results show that, even today, the agriculture is significant in the rural areas, and its and extensive cross-industry relationships, and only a well-functioning agricultural can be the base of a harmonious rural development. So the promotion and development of the multi-functional agriculture, as part of the green economy cannot be circumvented by the Hungarian rural areas. Another important issue that there are not only significant regional differences in the environmental review of land use side, but in the economic and social indicators specify the sector as well. In our opinion, not just in the agro-environmental special programs should be applied with different regional preferences, but in the entire agrarian subvention system as well. The grant targets and the development of related tools connected to it would be appropriate at a regional level. On the areas with good endowments, (because of the already low landscape and biological diversity) a large-scale, precision farming approach ${ }^{4}$ is recommended. Target areas of this measurements can be the small areas and the places which are perfect for intensive farming, such: Backa, Mezőföld, Kisalföld, and some of Békés county's landscapes and some areas of Jasz-Nagykun-Szolnok and Hajdu-Bihar counties.

On the sandy lands of the Danube and Tisza rivers and the south part of Békes County - where a significant number of fields are cultivated by small farmers - a competitive family economic model should be supported. All these activities would be producing fruits and vegetables, grazing animals within the framework of organic farming. The latter activity also should serve the interests of nature conservation on the grasslands of Kiskunság and Koros-Maros National Park.

The high agricultural density of the Northern Great-Plain (especially in Szabolcs-Szatmar county), is combined with small-scale and low income, of which that the social functions of agriculture should be strengthen with the landscape maintenance. It is primarily that we should help the establishment of regional self-sufficiency, vocational training (agricultural related, and a lot of vocational education), and social cooperatives.

Based on our results of 14 mostly hilly, highland areas (Transdanubia, Northern Mountains, Mecsek and Somogy hills), we consider to give high priority to forest areas and for further development and support of them. Promoting the bio-and organic farming is possible with supports but with other resources. A good example for that is the Hungarian rye production which is, essentially within the framework of organic farming. The reason is that the market price may not be adequate to earn the cost of pest control. So in our view, after a proper control the domestic crop should be declared and sold as organic product. There would be demand from our west neighbors for these organic products.

In addition, we should take steps towards diversification, the position on standing on more feet, and develop incentives and political support. Here - along much more opportunities - especially the cultivation of medicinal plants should be mentioned (in the future, the limited use of chemicals will be allowed). Hungary in this area in the 1970s and 1980s considered to be a real superpower. After the compensation, it was strongly reduced and the collection has been so dominant. However, both Western and Eastern Europe, people are increasingly turning to natural substances in the health field. Thus, in the longer term, Hungary can also be an important place for the cultivation of herbs

4 This "concept" and technology is that the agricultural board, within the local context in line with the injected nutrients (fertilizer and organic manure), pesticides and seeds. The production method is designed to optimize the return on invested capital, so that you minimize the negative environmental effects (Tamás 2001). 
industry and could improve the income to herbs industry. The listed programs and supporting goals - apart from preserving rural jobs - can have further advantages, like strengthening the intellectual population, as it needs highly qualified human resources.

All of these can increase - besides of the available human capital on the settlements - the implantation of added high valued activities, such as in the practice of rural development in the U.S. (Whitener, Parker 2005).

\section{CONCLUSIONS}

An outstanding result of our research is that, agriculture may become the catalyst to Green Economic Development in Hungary due to its strong links to other sectors. Thanks to the multiplicator effect of green agrarian development on other sectors, the latter may generate positive processes in environmental protection and rural society as well. Hungarian agriculture as well challenges involved in energy in two ways: on one hand, the Energy Efficiency of production must be enhanced, and this is crucial since the realization of efforts of WTO Negotiations directed at the liberalization of the agricultural trade would raise competitiveness of the Hungarian products, on the other hand, the utilization of biomass for energy purposes would reduce the energy-import dependence of the country, Increase the stability of the market of agricultural products, improve the profitability of the agrarian sector and promote the creation of rural jobs. Our research devoted special attention on how the theoretical foundations of green economy are validated in local spatial development policy (integrated urban development).

\section{REFERENCES}

Ángyán J., 2003a, A környezet- és tájgazdálkodás agroökológiai, földhasználati alapozása (Agroecological and land-use based environment and landscape management). Hungarian Academy of Science. Dsc thesis, Gödöllő HUN.

Ángyán J., 2003b, Védett és érzékeny természeti területek mezögazdálkodásának alapjai (Agricultural management basics of protected and sensitive areas). http://www.tankonyvtar. hu/mezogazdasag/vedett-erzekeny-080906-371.

Dinya L., 2008, Biomassza alapú fenntartható energiagazdálkodás (Biomass based energy management). Hungarian Science Festival, Formal Scientific Meeting, 3 Nov 2008. http://videotorium. $\mathrm{hu} / \mathrm{hu} /$ recordings/details/119,Biomassza_alapu_fenntarthato_energiagazdalkodas.

Habitat Directive, 1992, Council Directive 92/43/EEC on the Conservation of natural habitats and of wild fauna and flora. 21 May 1992.

Tamás J., 2001, Preciziós mezőgazdaság. Mezőgazdasági Szaktudás Kiadó, Budapest.

Territorial Agenda of the EU, 2011, Towards an Inclusive, Smart and Sustainable Europe of Diverse Regions. Informal Ministerial Meeting of Ministers responsible for Spatial Planning and Territorial Development on 19th May 2011 in Gödöllö, Hungary.

United Nations (UN), 2009, Global Green New Deal. An Update for the G20 Pittsburgh Summit. UNEP.

Whitener L.A., Parker T., 2005, Policy Options for a Changing Rural America, Amber Waves, 5, (Special Issue), 58-65. 